\title{
Antioxidant effect of lutein protects against oxidative damage to porcine spermatozoa
}

\author{
Gavazza, M. ${ }^{1}$; Marmunti, M. ${ }^{1}$ Compagnoni, M. ${ }^{2}$; Palacios, A. ${ }^{1}$ \\ ${ }^{1}$ Cátedra de Bioquímica; ${ }^{2}$ Laboratorio Reprod. Anim., Facultad de \\ Cs. Veterinarias, Universidad Nac. La Plata, Buenos Aires, Argentina. \\ E-mail: marianagavazza2002@yahoo.com.ar
}

\begin{abstract}
Gavazza, M.; Marmunti, M.; Compagnoni M.; Palacios, A.: Antioxidant effect of lutein protects against oxidative damage to porcine spermatozoa. Rev. Vet. 30: 1, 7-11, 2019. Boar sperm is especially susceptible to peroxidative damage generated by reactive oxygen species (ROS). Chemiluminescence was initiated by incubating porcine semen in an in vitro ascorbate- $\mathrm{Fe}^{++}$system, a technique that allows the evaluation of oxidative stress in these cells. Lutein is known for its antioxidant effects, chemically it is a dihydric derivative of $\alpha$-carotene and belongs to the group of xanthophylls. The main objective of this study was to investigate the antioxidant effect of lutein on boar spermatozoa. The effect of lutein was analyzed by two methods: 1) by adding lutein: the sperm samples were placed in an in vitro ascorbate$\mathrm{Fe}^{++}$system, during $120 \mathrm{~min}$ at $37^{\circ} \mathrm{C}$ adding increasing amounts of lutein $(50,150$ and 250 $\mu \mathrm{g}$ ) per $\mathrm{mg}$ of protein and 2) by incubation with lutein in an in vitro ascorbate- $\mathrm{Fe}^{+2}$ system, for $120 \mathrm{~min}$ at $37^{\circ} \mathrm{C}$, using spermatozoa obtained from porcine semen samples previously incubated with lutein $(0.15$ and $0.25 \mathrm{mg} / \mathrm{ml})$ during $24 \mathrm{~h}$ at $15^{\circ} \mathrm{C}$. In both methods a control group (without lutein) was used. Peroxidation was measured by chemiluminescence using a liquid scintillation counter, the light emission being quantified in cpm (counts per minute). Analyzing the effect of lutein by the two methods, it was observed that the total amount of $\mathrm{cpm} / \mathrm{mg}$ of protein originated by chemiluminescence was lower in samples obtained from the lutein group than in the control group (without lutein). Total chemiluminescence (cpm total) was lower in samples obtained from the lutein group than in the control group (without lutein), with a significance of $p<0.005$. Percent inhibition of peroxidation was not concentration dependent. These results would demonstrate that lutein could act as an antioxidant that would protect the membranes of the sperm from oxidative damage.
\end{abstract}

Key words: porcine, spermatozoa, reactives oxygen species, chemiluminescence, lutein.

\section{Resumen}

Gavazza, M.; Marmunti, M.; Compagnoni M.; Palacios, A.: El efecto antioxidante de la luteína protege a los espermatozoides porcinos contra el daño oxidativo. Rev. Vet. 30: 1, 7-11, 2019. El esperma de cerdo es especialmente susceptible al daño peroxidativo generado por las especies reactivas de oxígeno (ERO). La quimioluminiscencia se inició incubando semen porcino en un sistema in vitro ascorbato- $\mathrm{Fe}^{++}$, técnica que permite evaluar el estrés oxidativo en estas células. La luteína es conocida por sus efectos antioxidantes, químicamente es un derivado dihídrico del $\alpha$-caroteno y pertenece al grupo de las xantofilas. El objetivo principal de este estudio fue investigar el efecto antioxidante de la luteína en espermatozoides de verracos. El efecto de la luteína se analizó por dos métodos: 1) por adición de luteína: las muestras de espermatozoides se colocaron en un sistema in vitro ascorbato- $\mathrm{Fe}^{+2}$ dependiente, durante $120 \mathrm{~min}$ a $37^{\circ} \mathrm{C}$ adicionando cantidades crecientes de luteína $(50,150$ y $250 \mu \mathrm{g}$ ) por mg de proteína y 2) por incubación con luteína: también en un sistema in vitro ascorbato- $\mathrm{Fe}^{+2}$ dependiente, durante $120 \mathrm{~min}$ a $37^{\circ} \mathrm{C}$ se utilizaron espermatozoides obtenidos de muestras de semen porcino previamente incubados con luteína $(0,15$ y $0,25 \mathrm{mg} / \mathrm{ml})$ durante $24 \mathrm{~h} \mathrm{a} 15^{\circ} \mathrm{C}$. En ambos métodos se utilizó un grupo control (sin luteína). La peroxidación fue medida por quimioluminiscencia, utilizando un contador de centelleo líquido, siendo la emisión lumínica cuantificada en cpm (cuentas por minuto). Analizando el efecto de la luteína por los dos métodos anteriormente mencionados, se observó que la cantidad total de $\mathrm{cpm} / \mathrm{mg}$ de proteína originada por quimioluminiscencia, fue menor en muestras obtenidas del grupo luteína que en el grupo control (sin luteína). Se observó que la quimioluminiscencia total (cpm totales) fue menor en muestras obtenidas del grupo luteína que en el grupo 
control (sin luteína), con una significancia de $\mathrm{p}<0,005$. Los porcentajes de inhibición de la peroxidación no fueron dependientes de la concentración. Estos resultados demostrarían que la luteína podría actuar como un antioxidante que protegería las membranas de los espermatozoides del daño oxidativo.

Palabras clave: porcino, espermatozoides, especies reactivas de oxígeno, quimioluminiscencia, luteína.

\section{INTRODUCTION}

Severe oxidative stress progressively leads to cell dysfunction and ultimately cell death. Oxidative stress is defined as an imbalance between pro-oxidants and/ or free radicals on the one hand, and anti-oxidizing systems on the other. The oxygen required for living may indirectly be responsible for negative effects; these deleterious effects are due to the production of free radicals, which are toxic for the cells (superoxide anions, hydroxyl radicals, peroxyl radicals, hydrogen peroxide, hydroperoxides and peroxinitrite anions) ${ }^{7}$.

Free radical attacks are responsible for cell damage and the targeted cells are represented by the cell membranes, which are particularly rich in unsaturated fatty acids, sensitive to oxidation reactions; DNA is also the target of severe attacks by reactive oxygen species $(\mathrm{ROS})^{7}$.

High amounts of polyunsaturated fatty acid are found in the mammalian spermatozoa membranes, thereby making them susceptible to lipid peroxidation. Although, free radicals and ROS play major roles in reproduction, they are strongly associated with oxidative stress. Notably, antioxidant such as vitamin E and C, carotenoids and carnitine have been found beneficial in restoring a balance between ROS generation and scavenging activities. There are emerging evidences that herbal products can also boost male reproductive functions ${ }^{1}$.

Lutein is a dihydroxylated derivative of $\alpha$-carotene, a chemical compound belonging to the group of xanthophylls. It is a yellow pigment found in plants, algae, photosynthetic bacteria and egg yolk. Because animals do not produce lutein, it is included in food supplements as an antioxidant.

Along with zeaxanthin are found in the ocular macula, however, these compounds are not transformed into retinol. It is related to the reduction of degeneration of the ocular macula, having as effect a better vision and prevents the progression of cataracts. It is also considered as a skin filter for light of shorter wavelength (blue and violet) ${ }^{6}$.

Oxidative stress plays a major role in the life and death of mammalian spermatozoa. These gametes are professional generators of ROS, which appear to derive from three potential sources: sperm mitochondria, cytosolic L-amino acid oxidases, and plasma membrane nicotinamide adenine dinucleotide phosphate oxidases.

The oxidative stress created via these sources appears to play a significant role in driving the physiologi- cal changes associated with sperm capacitation through the stimulation of a cyclic adenosine monophosphate/ protein kinase A phosphorylation cascade, including the activation of extracellular signal regulated kinaselike proteins, massive up-regulation of tyrosine phosphorylation in the sperm tail, as well as the induction of sterol oxidation.

When generated in excess, however, ROS can induce lipid peroxidation that, in turn, disrupts membrane characteristics that are critical for the maintenance of sperm function ${ }^{18}$, including the capacity to fertilize an egg. Furthermore, the lipid aldehydes generated as a consequence of lipid peroxidation bind to proteins in the mitochondrial electron transport chain, triggering yet more ROS generation in a self-perpetuating cycle.

The high levels of oxidative stress created as a result of this process ultimately damage the DNA in the sperm nucleus; indeed, DNA damage in the male germ line appears to be predominantly induced oxidatively, reflecting the vulnerability of these cells to such stress. Extensive evaluation of antioxidants that protect the spermatozoa against oxidative stress ${ }^{3}$.

Porcine semen preserved at $15^{\circ} \mathrm{C}$ maintained the seminal quality for a limited time. In recent years, work has been done on the cooling stage, a period in which changes occur in the integrity of the plasma membrane. These are especially due to a destabilization in the antioxidant system of spermatozoa. This system preserves sperm cells from oxidative stress, which affects their survival and fertilizing ability.

The boar spermatozoon is especially susceptible to peroxidative damage generated by ROS, due to the high proportion of polyunsaturated fatty acids present in its membranes. ROS are naturally formed as a byproduct of normal oxygen metabolism and are involved in physiological sperm functions. When the balance between ROS production and detoxification, its neutralization by the antioxidants (Ax) is interrupted, excess ROS creates an oxidative stress, which blocks the cellular metabolism and decreases sperm motility. The addition of $A x$ in refrigeration could minimize sperm damage generated by ROS ${ }^{21}$.

The measurement of the light emission from a chemical reaction is very analytically useful because, under appropriate experimental conditions, the light output is directly related to the analytical concentration, thus allowing a precise and sensitive quantitative analysis. In addition, light emission is usually represented by steady-state kinetics, which simplifies sample handling and measurement procedures. Chemilu- 
minescence has been widely used as an indicator of the formation of reactive oxygen species in whole cells and organs, allowing the study of a number of pathophysiological conditions related to oxidative stress ${ }^{18}$.

The purpose of this study was analyze the susceptibility to non-enzymatic peroxidation by the in vitro addition of different doses of the vegetable antioxidant lutein on porcine spermatozoa and incubate semen samples previously with the vegetable antioxidant lutein and them subject the spermatozoa to a peroxidation process.

\section{MATERIALS AND METHODS}

Chemicals. Bovine serum albumin (BSA) (Fraction V) was obtained from Wako Pure Chemical Industries, Japan. L (+) ascorbic acid was from Merck Laboratories. Lutein was kindly supplied by Sigma Laboratory. All other reagents and chemicals were of analytical grade from Sigma.

Animals, handling, evaluation and processing of ejaculates. Procedures involving animals were in accordance with the recommendation of the Bioethics Committee of UNLP (National University of La Plata). The fresh boar semen samples $(n=6)$ kept at $15^{\circ} \mathrm{C}$ were obtained from stallions of the Faculty of Veterinary Sciences UNLP and of differents commercial establishments in the province of Buenos Aires, Argentina.

Sperm rich ejaculate fractions (cross-breeding) obtained from three boars were collected by gloved-hand technique and filtered with gauze during collection and evaluated for conventional semen characteristics. Ejaculates that showed progressive motility $>70 \%$, viable cells $>70 \%$, normal spermatozoa $>80 \%$, and normal acrosomal integrity $>80 \%$ were used.

Semen concentration was calculated by a manual count of sperm cells on a hemacytometer Bürker chamber. After evaluation, semen was diluted 1:4 in a commercial extender and transferred to $100 \mathrm{ml}$ tubes, containing a dose of 6 billion spermatozoa each, cooled to $17^{\circ} \mathrm{C}$, and sent by mail, packaged in insulated containers under conditions of monitored temperature. The extended semen arrived at the Reproduction Lab., Faculty of Veterinary Sciences (La Plata, UNLP) the day after collection.

At the laboratory, it was evaluated for semen quality: 1) percentage of progressively motile spermatozoa placed under a coverslip in the center of a prewarmed $37^{\circ} \mathrm{C}$ plate; 2) percentage of viable cells, by eosin-nigrosin staining; 3 ) percentage of normal spermatozoa morphology and of acrosomal integrity, by viewing wet mounts of extended semen fixed in buffered $8 \%$ glutaraldehyde solution under a phase contrast microscope at a magnification of $1000 x$.

An aliquot of each of the kept at $15^{\circ} \mathrm{C}$ boar samples were sent from the Reproduction Lab. to the Biochemical Laboratory (Faculty of Veterinary Sciences, UNLP).
Preparation of fresh boar semen samples. An aliquot $(1 \mathrm{ml})$ of semen of each samples was centrifuged at $800 \mathrm{x} g$ for $10 \mathrm{~min}$, sperm pellets were separated, and washed by resuspending in PBS (phosphate buffer salinum) and recentrifuging (three times). After the last centrifugation, $1 \mathrm{ml}$ of deionized water was added to spermatozoa ${ }^{9}$ and they were snap-frozen and stored at $-20^{\circ} \mathrm{C}$ and used within a week of its preparation, after one cycle of freezing and thawing. All operations were performed at $4^{\circ} \mathrm{C}$.

Non-enzymatic spermatozoa peroxidation. Chemiluminescence and peroxidation were initiated by adding ascorbate- $\mathrm{Fe}^{+2}$ to spermatozoa preparations ${ }^{23}$. Spermatozoa samples (1 $\mathrm{mg}$ of protein) were incubated at $37^{\circ} \mathrm{C}$ with $0.01 \mathrm{M}$ phosphate buffer ( $\left.\mathrm{pH} 7.4\right), 0.4 \mathrm{mM}$ ascorbate, final volume: $1 \mathrm{ml}$.

Phosphate buffer is contaminated with sufficient iron to provide the necessary ferrous or ferric iron for peroxidation (final concentration in the incubation mixture was $2.15 \mu \mathrm{M}){ }^{19}$. Pellets were incubated in vitro with increasing amounts of lutein $(0.05$ to $0.25 \mathrm{mg}$ / $\mathrm{ml})$ per $\mathrm{mg}$ of sperm protein.

In addition, samples of porcine semen previously incubated with lutein $(0.15$ and $0.25 \mathrm{mg} / \mathrm{ml})$ were incubated for $24 \mathrm{~h}$ and maintained at $15^{\circ} \mathrm{C}$. In all cases, spermatozoa preparations which lacked ascorbate- $\mathrm{Fe}^{+2}$ (control) were carried out simultaneously.

Chemiluminescence was measured as counts per min (cpm) in a liquid scintillation analyzer Packard 1900 TR. Membrane light emission was determined over $120 \mathrm{~min}$ period, and recorded as cpm every $10 \mathrm{~min}$ and the sum of the total chemiluminescence was used to calculate $\mathrm{cpm} / \mathrm{mg}$ protein.

Protein determination. Proteins were determined by the method of Lowry et al. (1951) using BSA as standard ${ }^{14}$.

Statistical analysis. The data were subjected to the Student's t-test. Data were expressed as mean \pm SD. The 0.05 level was selected as the point of minimal statistical significance. Statistical criterion for significance was selected at different $p$ values and indicated in each case.

\section{RESULTS}

Effect of lutein by addition to the in vitro system ascorbate-Fe ${ }^{++}$on spermatozoa peroxidation. Spermatozoa incubation in the presence of ascorbate- $\mathrm{Fe}^{++}$ resulted in membrane peroxidation as evidenced by light emission (chemiluminescence) when the control and ascorbate- $\mathrm{Fe}^{++}$groups were compared. Values were $339.66 \pm 72.01$ in the control group while $535.33 \pm$ 65.45 in the ascorbate- $\mathrm{Fe}^{++}$group.

After incubation of spermatozoa in an ascorbate$\mathrm{Fe}^{++}$system at $37^{\circ} \mathrm{C}$ for 120 minutes in the presence of increasing amounts of lutein $(50 \mu \mathrm{g}, 150 \mu \mathrm{g}$ and 
$250 \mu \mathrm{g})$ per mg protein, the cpm originated from the light emission was lower in the lutein group than in the ascorbate-Fe ${ }^{++}$group. Values were $535.33 \pm 65.45$ in the ascorbate- $\mathrm{Fe}^{++}$group while with the addition of 0.05 , 0.15 and $0.25 \mathrm{mg}$ of lutein were $304 \pm 17.68,301.33 \pm$ 30.44 and $310 \pm 20.85$ respectivelly, the significance was $\mathrm{p}<0.005$ (Figure 1).

Spermatozoa obtained from porcine semen incubation with lutein: chemiluminescence. The values of light emission of spermatozoa obtained from porcine semen incubated with lutein (Figure 2) showed statistically differences $(\mathrm{p}<0.005)$, when the spermatozoa control group (ascorbate-Fe ${ }^{++}$without lutein) were compared with the spermatozoa incubated group with 0.15 and $0.25 \mathrm{mg} / \mathrm{ml}$ of lutein.

\section{DISCUSSION}

Peroxidation is recognized as a harmful process for spermatozoa, leading to loss of motility and reduced fertilization capacity in spermatozoa of many species, including man ${ }^{2}$. Peroxidation occurs spontaneously in mammalian spermatozoa ${ }^{12}$ and is greatly improved in human subfertile ejaculates ${ }^{4}$ or in stored semen of birds ${ }^{2,22}$.

It is believed that the mechanisms by which ROS disrupt sperm function imply the peroxidation of the polyunsaturated fatty acids present in the sperm plasma membrane and this process plays an important role in the pathophysiology of male infertility ${ }^{2}$. ROS increase the fragmentation of $\mathrm{DNA}^{2}$, modify the cyto-

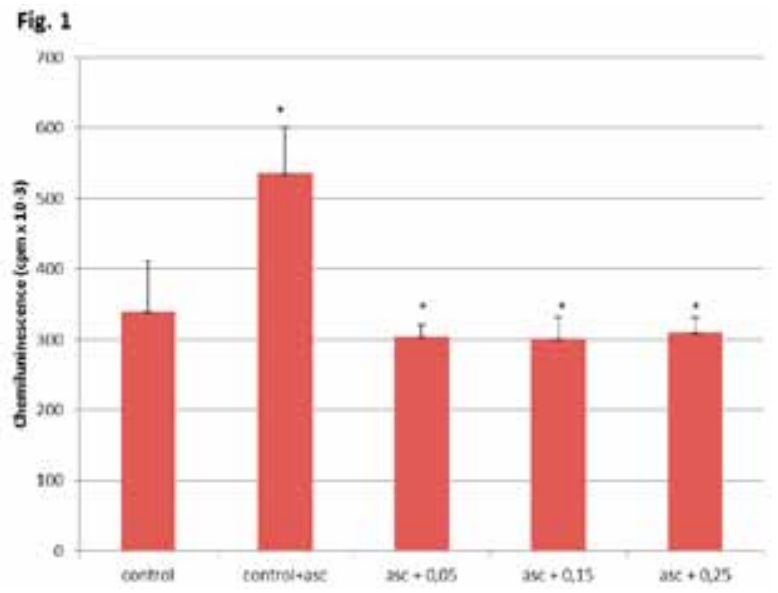

Figure 1. Effect of lutein by addition to the in vitro system ascorbate-Fe ${ }^{++}$on spermatozoa peroxidation. Results are expressed as mean \pm SD of six independent experiments. The values of light emission showed statistically differences $(* p<0.005)$, when the control (without ascorbate) and ascorbate-Fe ${ }^{++}$(with ascorbate- $\mathrm{Fe}^{++}$) spermatozoa membrane groups were compared. Similarly, differences $(* p<0.005)$ were found when was compared ascorbate- $\mathrm{Fe}^{++}$with ascorbate and antioxidant addition $(0.05,0.15$ and $0.25 \mathrm{mg} / \mathrm{ml})$ spermatozoa membrane groups. skeleton ${ }^{13}$, affect the development of the sperm axon ${ }^{10}$ and inhibit sperm fusion.

Porcine semen has high levels of unsaturated fatty acids. In previous studies we have shown that these fatty acids exposed to an in vitro system, in the presence of ascorbate, were vulnerable to peroxidation. In the presence of lycopene, a natural antioxidant that has a high in vitro ability to bind to singlet oxygen, a protective effect against peroxidation was observed, since the main unsaturated fatty acids were not affected by this process.

The main objective of this study was to investigate the antioxidant effects of lutein on boar spermatozoa. In vitro peroxidation research is desirable for the elucidation of possible peroxide formation mechanisms in vivo ${ }^{8}$, since membrane composition causes vulnerability to peroxidative degradation ${ }^{17}$.

Although important studies have been carried out to characterize changes in the structure, composition and physical properties of membranes undergoing oxidation $5,15,16,20$, it is necessary to know how biological compounds with antioxidant properties contribute to the protection of specialized membranes against the harmful effects produced by reactive species of oxygen and other free radicals.

The actual evidence shows that lutein has an effective antioxidant activity ${ }^{11}$, with lutein being able to improve the biochemical parameters and reduce the formation of inflammatory cytokines, thus avoiding oxidative stress.

In conclusion, our results agree with the hypothesis that lutein could protect the membranes from oxidative damage.

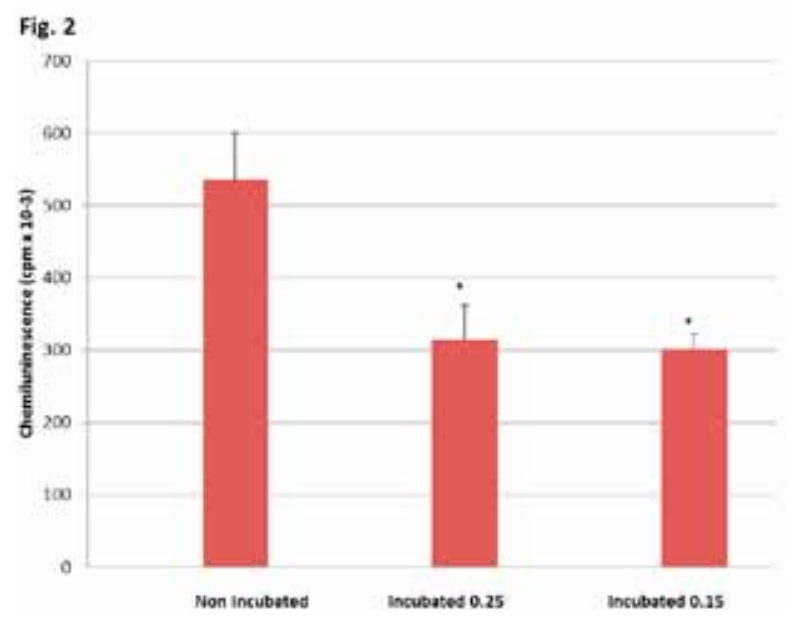

Figure 2. Spermatozoa obtained from porcine semen incubation with lutein: chemiluminescence. Results are expressed as mean \pm SD of six independent experiments. After non enzymatic peroxidation, the values of light emission showed statistically differences $\left({ }^{*} \mathrm{p}<0.005\right)$ between the lutein incubated spermatozoa membrane group compared with the control + ascorbate group (non incubated). 
Acknowledgements. This work was supported by Grant 11/V227 of Secretaría de Ciencia y Técnica, National University of La Plata, Argentina.

\section{REFERENCES}

1. Adewoyin $\mathbf{M}$ et al. 2017. Male infertility: the effect of natural antioxidants and phytocompounds on seminal oxidative stress. Diseases 5: 1-26.

2. Aitken RJ. 1994. A free radical theory of male infertility. Reprod Fertil Dev 6: 19-24.

3. Aitken RJ. 2017. Reactive oxygen species as mediators of sperm capacitation and pathological damage. Mol Reprod Dev 84: 1039-1052.

4. Alvarez JC, Storey BT. 1989. Role of gluthatione peroxidase in protecting mammalian spermatozoa from loss of motility caused by spontaneous lipid peroxidation. Gamete Res 23: 77-90.

5. Ayala A, Muñoz MF, Argüelles S. 2014. Lipid peroxidation: production, metabolism, and signaling mechanisms of malondialdehyde and 4-hydroxy-2-nonenal. Oxid Med Cell Longev. http://dx.doi.org/10.1155/2014/360438, 31 pages.

6. Begoña OA. 2008, Efecto de "nuevos" nutrientes sobre la retina y la función visual. Rev Nutr Práct 12: 64-69.

7. Bonnefoy M, Drai J, Kostka T. 2002. Antioxidants to slow aging, facts and perspectives. Presse Med 31: 11741184.

8. Brand MD, Affourtit C, Esteves TC. 2004. Mitochondrial superoxide: production, biological effects, and activation of uncoupling proteins. Free Radic Biol Med 37: 755-767.

9. Dandekar SP, Nadkami GD, Kulkami VS, Punekar S. 2002. Lipid peroxidation and antioxidant enzymes in male infertility. J Posgrad Med 48: 186-189.

10. Hinshaw DB, Sklar LA, Bohl B. 1986. Cytoeskeletal and morphologic impact of cellular oxidant injury. $\mathrm{Am} \mathrm{J}$ Pathol 123: 454-464.

11. Larouche D et al. 2016. Evaluation of antioxidant intakes in relation to inflammatory markers expression within the normal breast tissue of breast cancer patients. Integr Cancer Ther Nov 30. pii: 1534735416676584 [Epub ahead of print].
12. Lenzi A et al. 2000. Lipoperoxidation damage of spermatozoa polyunsaturated fatty acids (PUFA): Sacavenger mechanism and possible therapies. Front Biosci 5: E1-E2.

13. Lopes S, Jurisicova A, Sun JG, Casper RF. 1998. Reactive oxygen species: potential cause for DNA fragmentation in human spermatozoa. Hum Reprod 13: 896-900.

14. Lowry OH, Rosebrough NJ, Farr AL, Randall RJ. 1951. Protein measurement with the Folin phenol reagent. J Biol Chem 193: 265-275.

15. Naserzadeh P, Hosseini MJ, Arbabi S. 2015. A comparison of toxicity mechanisms of cigarette smoke on isolated mitochondria obtained from rat liver and skin. Iran $J$ Pharm Res 14: 271-277.

16. Omotayo TI, Akinyemi GS, Omololu PA. 2014. Possible involvement of membrane lipids peroxidation and oxidation of catalytically essential thiols of the cerebral transmembrane sodium pump as component mechanisms of iron-mediated oxidative stress-linked dysfunction of the pump's activity. Redox Biol 4: 234-241.

17. Shichiri M. 2014. The role of lipid peroxidation in neurological disorders. J Clin Biochem Nutr 54: 151-160.

18. Spiteller G. 2003. Are lipid peroxidation processes induced by changes in the cell wall structure and how are these processes connected with diseases? Med Hypotheses 60: 69-83.

19. Terrasa A, Guajardo M, Catalá A. 2000. Selective inhibition of the non-enzymatic lipid peroxidation of phosphatidylserine in rod outer segments by alpha-tocopherol. $\mathrm{Mol}$ Cell Biochem 211: 39-45.

20. Vyssokikh MY, Antonenko YN, Lyamzaev KG. 2015. Methodology for use of mitochondria-targeted cations in the field of oxidative stress-related research. Methods Mol Biol 1265: 149-159.

21. Williams S et al. 2015. Boar semen cryopreservation: Results and advances in the technique. Analecta Vet 35: 17-25.

22. Wishart GJ. 1989. Physiological changes in fowl and turkey spermatozoa during in vitro storage. Br Poult Sci 30: 443-454.

23. Wright JR, Rumbaugh RC, Colby HD, Miles PR. 1979. The relationship between chemiluminescence and lipid peroxidation in rat hepatic microsomes. Archiv Biochem Biophys 192: 344-351. 